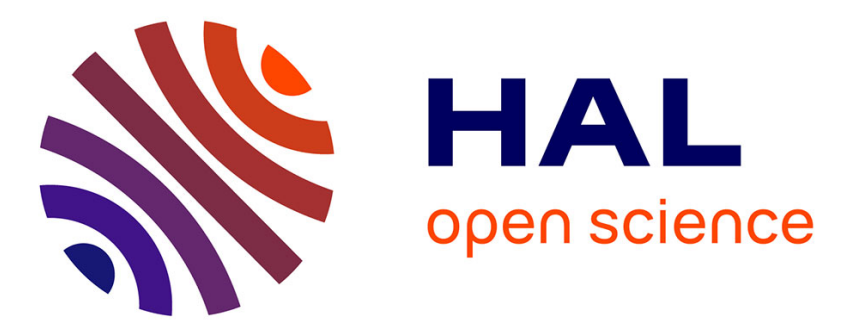

\title{
Impurity-defect interaction in polycrystalline silicon for photovoltaic applications. The role of hydrogen
}

\author{
A. Chari, P. de Mierry, A. Menikh, M. Aucouturier
}

\section{To cite this version:}

A. Chari, P. de Mierry, A. Menikh, M. Aucouturier. Impurity-defect interaction in polycrystalline silicon for photovoltaic applications. The role of hydrogen. Revue de Physique Appliquée, 1987, 22 (7), pp.655-662. 10.1051/rphysap:01987002207065500 . jpa-00245591

\section{HAL Id: jpa-00245591 https://hal.science/jpa-00245591}

Submitted on 1 Jan 1987

HAL is a multi-disciplinary open access archive for the deposit and dissemination of scientific research documents, whether they are published or not. The documents may come from teaching and research institutions in France or abroad, or from public or private research centers.
L'archive ouverte pluridisciplinaire HAL, est destinée au dépôt et à la diffusion de documents scientifiques de niveau recherche, publiés ou non, émanant des établissements d'enseignement et de recherche français ou étrangers, des laboratoires publics ou privés. 


\title{
Impurity-defect interaction in polycrystalline silicon for photovoltaic applications. The role of hydrogen
}

\author{
A. Chari, P. de Mierry, A. Menikh and M. Aucouturier \\ Laboratoire de Physique des Solides, C.N.R.S., 1, place Aristide Briand, 92195 Meudon Bellevue Principal \\ Cedex, France
}

(Reçu le 3 octobre 1986, accepté le 20 janvier 1987)

\begin{abstract}
Résumé. - Cet article résume les études effectuées par les auteurs sur le comportement physico-chimique de quelques impuretés $(\mathrm{P}, \mathrm{C}, \mathrm{H})$ dans le silicium. Les résultats portent sur : la diffusion et la ségrégation d'impuretés dans le silicium mono et polycristallin, la passivation des défauts recombinants par l'hydrogène, les interactions hydrogène-dopants. Un accent particulier est mis sur le comportement et la diffusion de l'hydrogène. Les résultats sont discutés en tenant compte de l'existence de mécanismes complexes d'interactions entre l'hydrogène et les impuretés ou les défauts.
\end{abstract}

\begin{abstract}
An overview of the studies done by the authors on the physicochemical behaviour of some impurities $(\mathrm{P}, \mathrm{C}, \mathrm{H})$ in silicon is given. Results concern : diffusion and segregation of impurities in mono and polycrystalline silicon, passivation of recombining defects by hydrogen, hydrogen-dopant interaction. A more focused interest is given on hydrogen diffusion and behaviour. The results are discussed, taking into account the existence of complex mechanisms of interaction between hydrogen and impurities or defects.
\end{abstract}

\section{Introduction.}

The development of polycrystalline silicon as a material for photovoltaic applications has raised several fundamental questions, in relation with technical implications. Technically speaking, the main problems arising when this new material was proposed can be summarized as follows :

i) What will be the consequence of the polycrystalline nature on the technology of solar cell fabrication? In other words, would the grain-boundaries or other defects (dislocation arrays, etc.) behave for instance as electronic of atomic diffusion short circuits, modifying the junction profile and/or the behaviour of the cell?

ii) Will the defects of the polycrystalline material hinder the photovoltaic properties of the material, that is generation and diffusion of the minority carriers, mobility of the majority carriers..., leading also to a degradation of the efficiency of the photovoltaic cells ?

iii) What would be the reliability of the solutions proposed to cure this above mentioned degradation : specific elaboration, modification of the process, defect passivation by hydrogen or other means, ...?

iv) Taking into account all these factors, what would be the maximum content of different defects (point, linear and two-dimensional) and of different impurities which can be allowed in a «solar grade" material to ensure a possible choice of this material for photocell fabrication?

These technical problems lead to several fundamental questions, concerning the physical and physico-chemical behaviour of polycrystalline silicon; one can mention for instance :

- structure of the defects of the material and its influence on electronic and photoelectric properties,

- possible grain-boundary fast diffusion and/or segregation of dopant and impurities,

- nature of the interactions between impurities and dopants or defects and their consequence on electronic properties,

- diffusion and solubility of the passivating impurities (e.g. hydrogen) in this material,

- passivation mechanism, i.e. the nature of in- 
teractions between the passivant and the recombination centre.

A large number of research work has been done and published, giving partial or definitive answers to some of these questions [1-4]. This paper summarizes some results obtained by the authors on polycrystalline and bicrystalline silicon, which can bring a contribution to the knowledge of the behaviour of polycrystalline silicon in the following fields :

- Grain-boundary diffusion and segregation of the impurities (phosphorus, carbon and hydrogen) and their consequences on the recombination at grain-boundaries, with a special interest on hydrogen passivation of bicrystals. silicon.

- Interactions between hydrogen and impurities, especially dopants, and consequences on electronic properties.

\section{Grain-boundary diffusion and segregation of im- purities.}

2.1 PhOSPhORus. - The preferential diffusion of phosphorus in silicon grain-boundaries may have, if it exists, important consequences on the diffused junction profile of the photovoltaic cells [5]. Systematic measurements were conducted on p-type (B doped, $\rho=1 \Omega \mathrm{cm}$ ) polycrystalline silicon elaborated by the R.A.D. process [6] or by ingot casting (Wacker Heliotronic).

A radioactivation method was used : phosphorus is diffused into the material by the conventional borosilicate glass process, at various temperatures, it is activated by neutron bombardment and the profiles are analysed by grinding and residual activity measurements [7] ; the results are summarized in figures 1 and 2. Bulk diffusion coefficients of $\mathrm{P}$ in $\mathrm{Si}$ are measured, but no grain-boundary preferential diffusion of $\mathrm{P}$ could be observed in this kind of material, neither from the penetration curves, nor from the observation of autoradiography.

The absence of grain-boundary diffusion observed here is in disagreement with results obtained by other laboratories $[5,8]$ on different materials. The reason is that R.A.D. and ingot cast polycrystalline silicon contain a large majority of grain-boundaries in coincidence or near from coincidence.

The measurements of phosphorus intergranular diffusivity mentioned [8] were obtained in recrystallized silicon with mostly random grain-boundaries.

2.2 CARBON. - Carbon is often a majority impurity of solar grade polycrystalline silicon. A study of carbon diffusion and segregation has been conducted on R.A.D. and Wacker polycrystalline silicon. A radioactive tracer method is used : the specimens are first coated with a layer of radioactive $\left({ }^{15} \mathrm{C}\right.$ labelled)

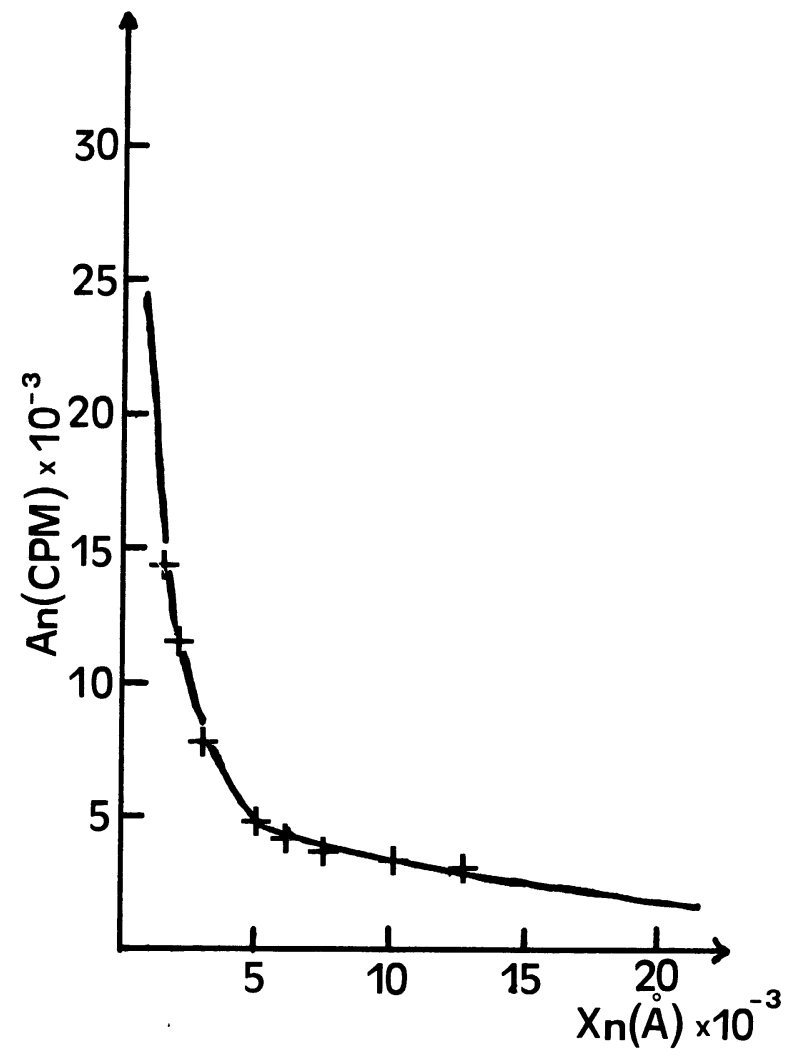

Fig. 1. - Variation of the ${ }^{32} \mathrm{P}$ residual activity $(\beta)$ as a function of the depth in polycrystalline silicon. Diffusion anneal : $T=900{ }^{\circ} \mathrm{C} ; t=5 \mathrm{~h}$; No grain-boundary diffusion tail is observed, and the full curve follows the $\mu A_{n}-\frac{\partial A_{n}}{\partial X_{n}}=K \exp \left(-X_{n}^{2} / 4 D t\right)$ law expected for a pure bulk diffusion.

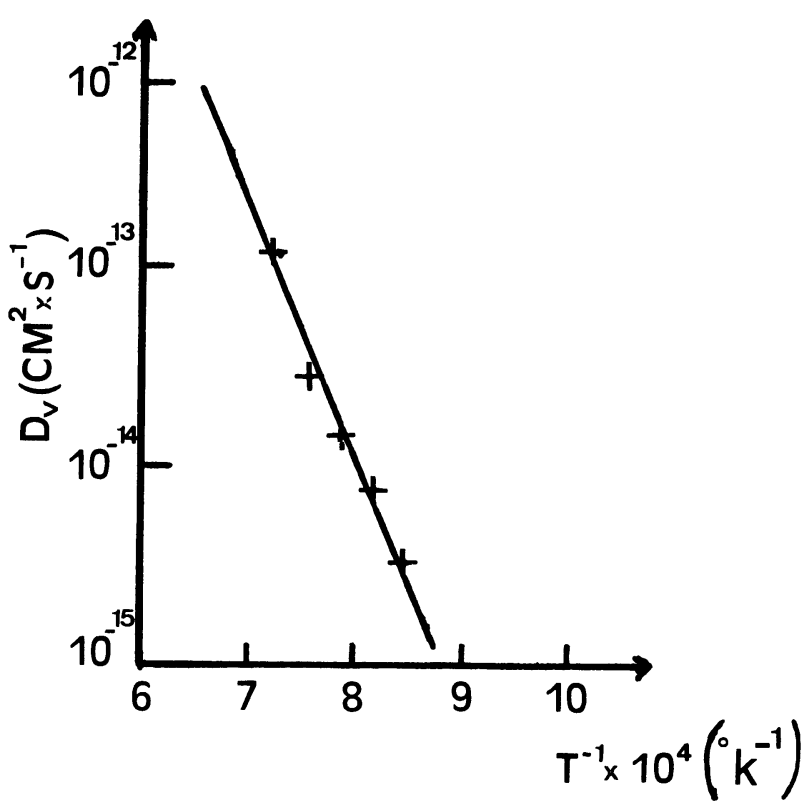

Fig. 2. - Arrhenius plot $\log (D)=f(1 / \pi)$ for bulk diffusion of phosphorus into polycrystalline silicon. 
SiC layer by annealing at moderate temperature $\left(900{ }^{\circ} \mathrm{C}\right)$ in a sealed silica tube containing the $\mathrm{Ba}^{14} \mathrm{Co}_{3}$ compound. Various heat treatments are then done and the ${ }^{14} \mathrm{C}$ profiles are analysed by grinding and residual activity measurements [7]. For the segregation studies, the specimens are first homogeneized by prolongated treatment at high temperature in the presence of $\mathrm{Ba}^{14} \mathrm{Co}_{3}\left(1200{ }^{\circ} \mathrm{C}\right.$, 20 days) and then annealed at various temperatures to provoke the expected segregation. The segregation is detected by autoradiography (conventional and high resolution) of the specimens [7].

The results on diffusion are summarized in figures 3 and 4 . Bulk diffusion coefficients of carbon into silicon are obtained at different temperatures but as for phosphorus no grain-boundary preferential diffusion could be detected in this kind of material, neither by analysis of the penetration curves, nor by autoradiography.

Furthermore a strong segregation tendency of carbon to grain-boundaries has been observed. Not all the grain-boundaries are affected by this segregation phenomenon (Fig. 5).

In order to try to correlate the segregation ability with the recombination behaviour of the grainboundaries, crossed experiments are conducted as follows [7, 9]. A cartography of minority carriers recombination centres is done by E.B.I.C. (Electron beam induced current) on given specimens and the same specimens are then homogeneized with ${ }^{14} \mathrm{C}$ and

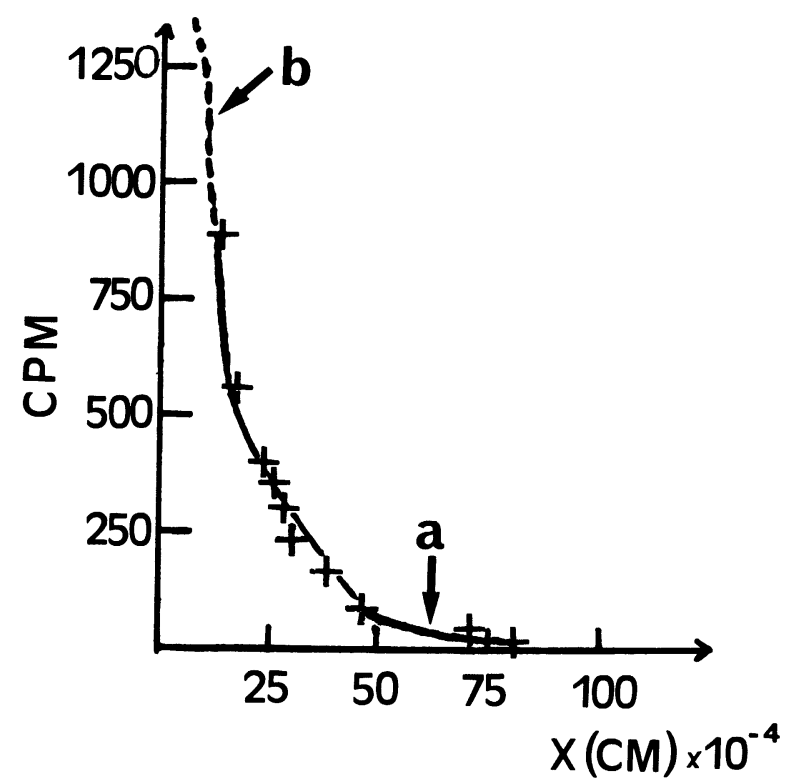

Fig. 3. - Variation of the ${ }^{14} \mathrm{C}$ residual activity $(\beta)$ as a function of the depth in polycrystalline silicon; diffusion anneal : $T=1353^{\circ} \mathrm{C} ; t=2 \mathrm{~h} 30 \mathrm{~min}$. The (b) part of the curve is perturbed by carbide precipitation phenomena. The (a) part follows the $\mu A_{n}-\frac{\partial A_{n}}{\partial X_{n}}=\left(-X_{n}^{2} / 4 D t\right)$ law expected for a pure bulk diffusion.

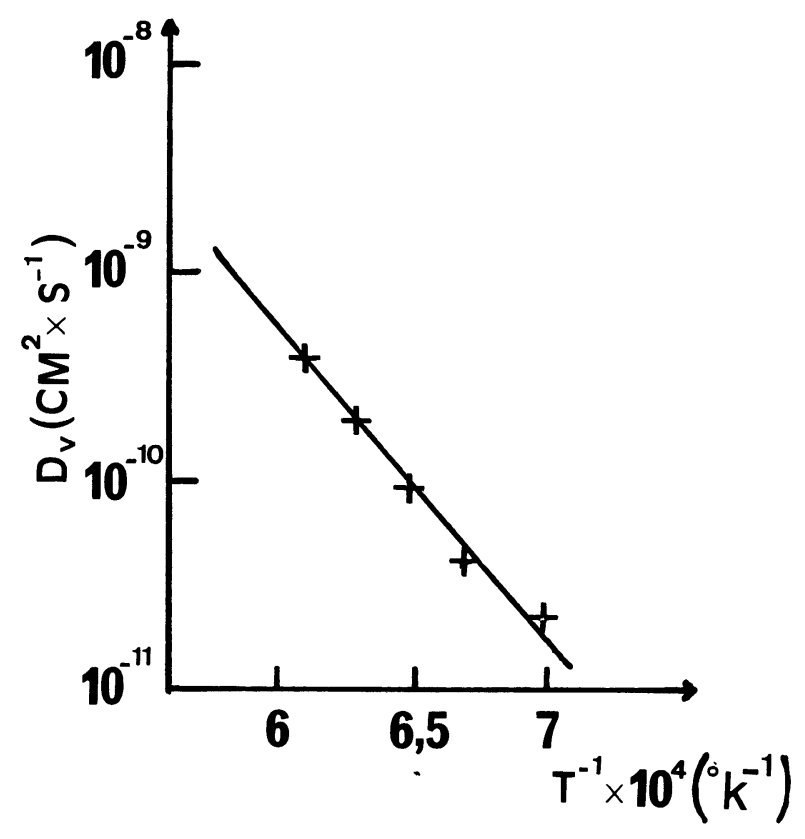

Fig. 4. - Arrhenius plot $\log (D)=f(1 / T)$ for bulk diffusion of carbon into polycrystalline silicon.

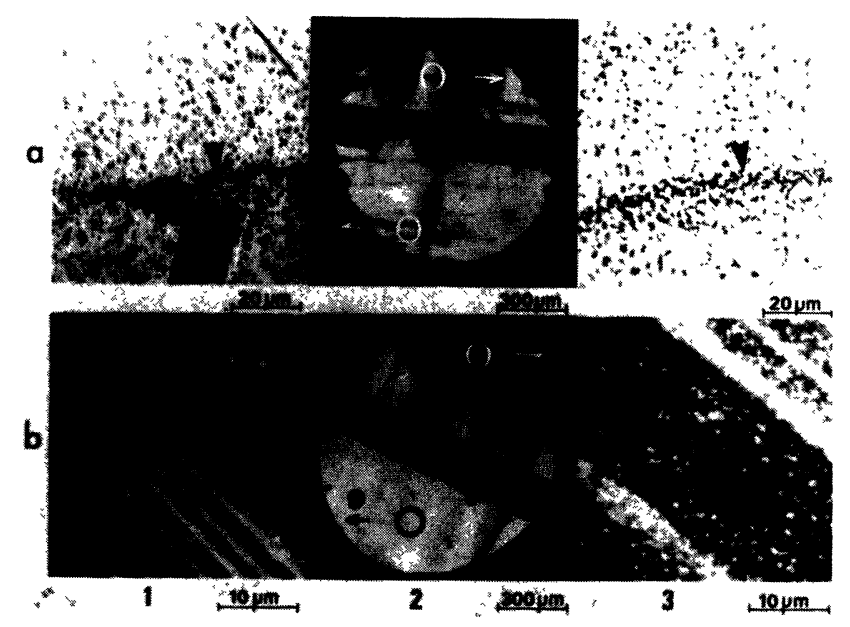

Fig. 5. - Autoradiography of ${ }^{14} \mathrm{C}$ coupled with EBIC image on a specimen of R.A.D. Black dots (optical micrograph) or white dot (S.E.M. micrograph) of the radiography indicate the presence of ${ }^{14} \mathrm{C}$. The black lines of the E.B.I.C. image indicate recombining boundaries.

annealed to obtain the grain-boundary segregation. The comparison between the autoradiography of ${ }^{14} \mathrm{C}$ and the E.B.I.C. images shows clearly (Fig. 5) that the recombining boundaries are also boundaries where a segregation of carbon is observed.

In an electron microscopy investigation of the same material, Sharko [10] has shown that carbon can be precipitated as $\mathrm{C}-\mathrm{Si}$ microparticles in some given grain-boundaries (mostly boundaries with a small deviation to coincidence). Both our and 
Sharko's results agree to prove that carbon segregation or precipitation is responsible for the minority carrier recombination behaviour of these grainboundaries.

2.3 HYDROGEN IN POLYCRYSTALS. - The hydrogen introduction and bulk diffusion aspect will be detailed in a following section 3 . The problem of the interaction between hydrogen and grain-boundaries is of great importance to understand the mechanisms of the recombination centre passivation by this element.

A radiotracer technique has been also used in that case : tritium $\left({ }^{3} \mathrm{H}\right)$ is introduced into p-type polycrystalline silicon (R.A.D. or Wacker) by cathodic polarization in acidic salt bath electrolyte at $150{ }^{\circ} \mathrm{C}$ labelled with tritiated water [11]. By photocurrent measurement it is checked that a certain passivation of the recombinating centres is thus obtained [12]. High resolution autoradiographies $(0.2 \mu \mathrm{m}$ resolution) are exposed on the specimens either in their bulk shape or as thin foils ready for transmission electron microscopy [13]. The observation of the autoradiography, either in the scanning electron microscope or in the transmission electron microscope (Fig. 6), shows a strong interaction of hydrogen with some given grain-boundaries, and more precisely, with linear defects (« extrinsic dislocations ») of these boundaries. So the segregation behaviour of hydrogen is then very similar to that of other impurities.

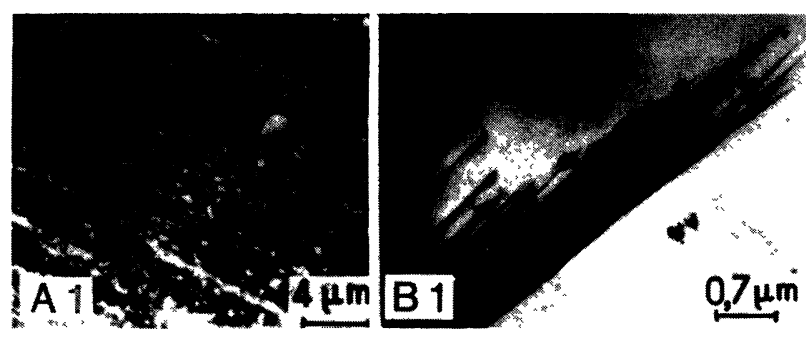

Fig. 6. - High resolution autoradiography of tritium on polycrystalline silicon charged with tritium at $150{ }^{\circ} \mathrm{C}$ in a salt bath electrochemical cell. A) Bulk specimen, S.E.M. observation, with dots indicate the presence of tritium. B). Thin foil, T.E.M. observation : black filaments indicate the presence of tritium.

2.4 HYDROGEN IN BICRYSTALS. - In order to try to understand more completely the role of grainboundaries impurities interaction, in the recombination and passivation phenomena, a systematic study was done on bicrystalline specimens. The material is a $\Sigma 25$ (710) bicrystal elaborated by Czochralski process. It is known [13] that this grain-boundary does not recombinate the minority carriers in the asgrown state, but that selected heat treatments $\left(450{ }^{\circ} \mathrm{C}, 750{ }^{\circ} \mathrm{C}, 900{ }^{\circ} \mathrm{C}\right)$ lead to recombination behaviour. This crucial role of the heat treatment suggests that impurity segregation and/or precipitation is responsible for the creation of recombination centres at this grain-boundary. The apparition and the influence of hydrogen on these recombination centres has been studied by the electrochemical L.B.I.C. (Light beam induced current) method [14].

The bicrystalline specimens are heat treated $\left(450{ }^{\circ} \mathrm{C}-24 \mathrm{~h} ; 750{ }^{\circ} \mathrm{C}-24 \mathrm{~h} ; 900{ }^{\circ} \mathrm{C}-24 \mathrm{~h}\right)$ under static high vacuum. The photocurrent cartography is obtained by laser (AsGa, $0.954 \mu \mathrm{m})$ local illumination through an electrochemical diode (HF $5 \%, E=$ -1 V/S.C.E.) and microscanning. The same specimens are then submitted to hydrogenation by microwave plasma annealing $(2450 \mathrm{MHz}, 60 \mathrm{~W}, 1 \mathrm{mBar}$ de $\left.\mathrm{H}_{2}\right)$ at $320{ }^{\circ} \mathrm{C}(6 \mathrm{~h})$ and the photocurrent cartography is again obtained by the same technique.

From the results (Fig. 7) the following observations can be drawn:

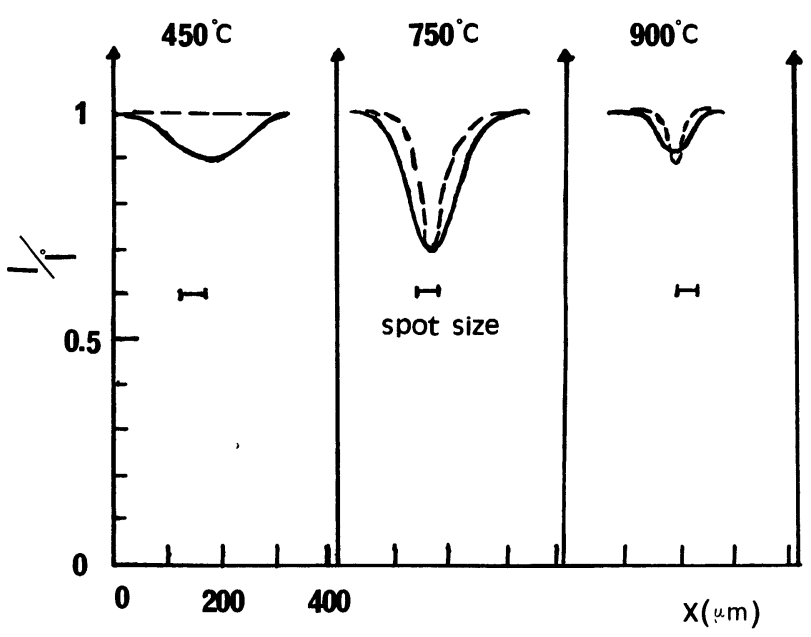

Fig. 7. - L.B.I.C. scanning (electrolytic diode) of a silicon bicrystal $(\Sigma=25,(710))$ after different heat treatment, before (-) and after (- - -) plasma hydrogenation. Incident light : $\mathrm{GaAs}$ laser $\left(\lambda=0.954 \mu \mathrm{m} ; \alpha^{-1}=\right.$ $50 \mu \mathrm{m}$; beam diameter $<30 \mu \mathrm{m})$.

The preceeding results [13] on the role of the thermal treatment are confirmed. The boundary is slightly recombining (recombination rate $s=5 \times$ $10^{3} \mathrm{~cm} . \mathrm{s}^{-1}$ ) after $4500^{\circ} \mathrm{C}$ and strongly recombining $\left(s=2.5 \times 10^{4} \mathrm{~cm} . \mathrm{s}^{-1}\right)$ after $750{ }^{\circ} \mathrm{C}$ and $900^{\circ} \mathrm{C}$ annealing. The hydrogen treatment leads to a complete passivation of the $450{ }^{\circ} \mathrm{C}$ annealed boundary but has no influence on the behaviour of the $750{ }^{\circ} \mathrm{C}$ and $900{ }^{\circ} \mathrm{C}$ annealed specimens. The penetration of hydrogen has been checked by S.I.M.S. (secondary ion mass spectroscopy) profiling after deuterium 
plasma annealing. This very recent result of a study still under continuation proves that : i) the impurity segregation responsible for the creation of recombining centres is not unique, as the $450^{\circ} \mathrm{C}$ annealing has not the same effect as the $750{ }^{\circ} \mathrm{C}$ or $900{ }^{\circ} \mathrm{C}$ annealing ; ii) hydrogen does not passivate all the recombination centres and interacts preferentially with the centres created at $450{ }^{\circ} \mathrm{C}$. An autoradiography study after tritium introduction is to be done on those bicrystals.

\section{Introduction and diffusion of hydrogen into silicon.}

Hydrogen can be introduced into silicon by several means : bombardment in a Kaufman source [14, 15], plasma annealing [16], electrolyte charging [12]. Plasma annealing and electrolyte charging have been investigated in the present study, in order to quantify the diffusion mechanisms of hydrogen. For this study, monocrystalline silicon is used as a first step.

\subsection{HIGH TEMPERATURE INTRODUCTION BY PLAS-} MA ANNEALING. - The diffusion profiles of hydrogen into silicon at high temperature are then studied by S.I.M.S. of deuterium (hydrogen is replaced by deuterium in the plasma atmosphere (1 mbar)). Two different plasma sources were used : a R.F. plasma $(13.56 \mathrm{MHz}, 20 \mathrm{~W}$, specimen inside the glow discharge) and a microwave plasma (2450 MHz, $60 \mathrm{~W}$, specimen outside the glow discharge).

Some results are given in figures 8 and 9 at various temperatures and for various materials: p-type $\left(6 \times 10^{16}\right.$ at. B. $\left.\mathrm{cm}^{-3}\right)$, n-type $\left(10^{18}\right.$ at. P. $\left.\mathrm{cm}^{-3}\right)$ and undoped. From this non-achieved investigation, some provisory conclusions may be drawn :

a) the solubility of hydrogen in silicon is in all case, "reverse", that is, decreasing when the temperature is raised.

b) the apparent solubility for given conditions (i.e. for a given plasma source), is strongly dependent on the doping type and doping level. It is one order of magnitude larger in p-type silicon than in ntype or undoped silicon.

c) the diffusion profiles cannot be analysed by a simple diffusion mechanism; each of them is the result of the addition of, at least, two diffusion profiles. The observation of such complex diffusion profiles has been already mentioned in studies on $p$ type silicon $[17,18]$, and the explanation usually given is the interaction phenomena between hydrogen and boron (see following Sect. 4).

d) the maximum values of the diffusion coefficients which can be deduced from the deepest part of the profiles are of the order of $10^{-12} \mathrm{~cm}^{2} . \mathrm{s}^{-1}$ at $150{ }^{\circ} \mathrm{C}$ and $10^{-11} \mathrm{~cm}^{2} \cdot \mathrm{s}^{-1}$ at $320^{\circ} \mathrm{C}$, in agreement with the literature [19]. It must be mentioned that
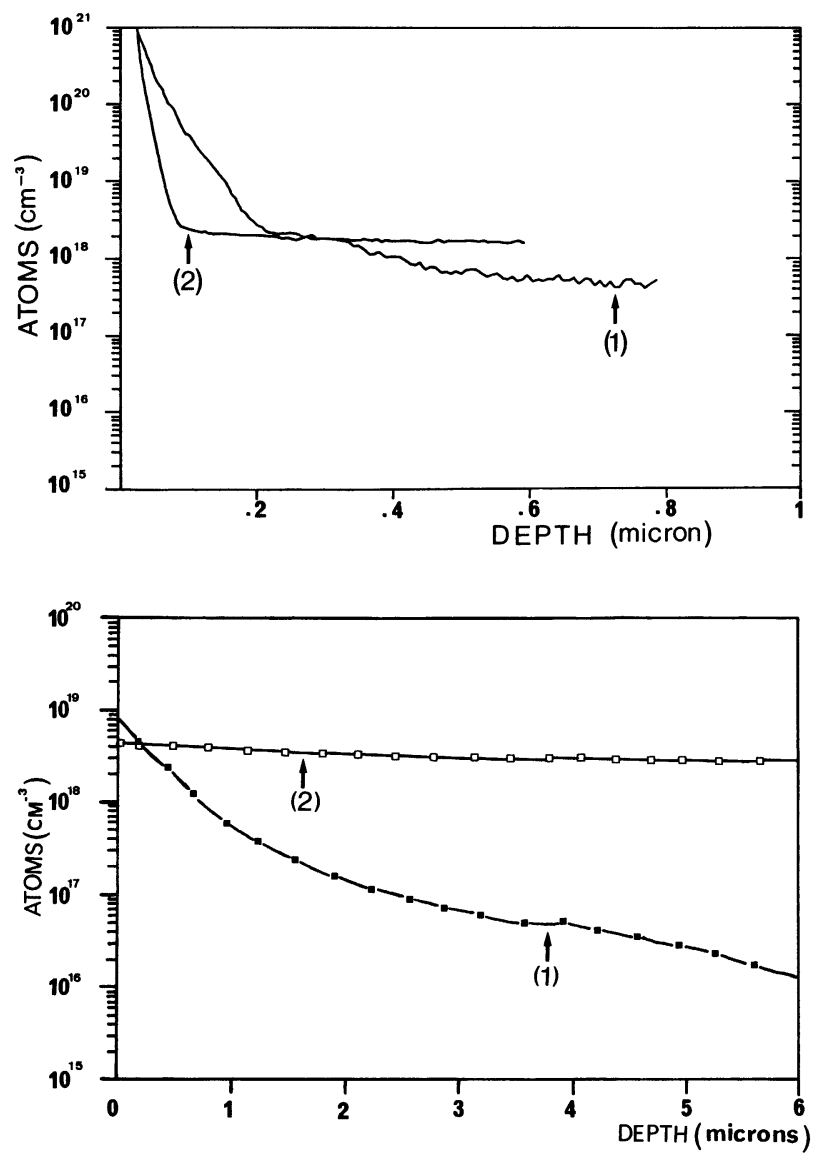

Fig. 8. - Deuterium S.I.M.S. profils in p-type $\left(6 \times 10^{16}\right.$ at. B. $\left.\mathrm{cm}^{-3}\right)$ in silicon after various deuterium plasma annealings. a) R.F. plasma ; (1) $T=150{ }^{\circ} \mathrm{C}$, $t=3 \mathrm{~h}$; (2) $T=260^{\circ} \mathrm{C}, t=3 \mathrm{~h}$. b) microwave plasma ; (1) $T=150{ }^{\circ} \mathrm{C} ; t=3 \mathrm{~h}$; (2) $T=320^{\circ} \mathrm{C}$; $t=3 \mathrm{~h}$.

these values concern hydrogen detectable for the given conditions of S.I.M.S. analysis (detection limit $10^{15}$ to $5 \times 10^{15}$ at. $\mathrm{cm}^{-3}$ of deuterium).

\subsection{ELECTROCHEMICAL PERMEATION OF HYDRO-} GEN. - The electrochemical permeation technique has been used to detect very small fluxes of hydrogen diffusing through a silicon membrane at room temperature [20]. In this kind of experiments, a thin $(\simeq 100 \mu \mathrm{m})$ membrane of monocrystalline silicon $(\mathrm{p}-$ type or n-type with a $\mathrm{n}^{+} / \mathrm{p}$ junction on one surface) is covered on both sides by a palladium layer. The «entry face » is exposed to an acidic solution $\left(\mathrm{H}_{2} \mathrm{SO}_{4}, 1 \mathrm{~N}\right)$ and cathodically polarized to produce atomic hydrogen (constant current $10 \mathrm{~mA} / \mathrm{cm}^{2}$ ). The "down stream face » is exposed also to an electrochemical cell anodically polarized $(V=$ $100 \mathrm{mV} / \mathrm{ECS}$ ) in $\mathrm{H}_{2} \mathrm{SO}_{4}, 1 \mathrm{~N}$. The anodic current $i_{\mathrm{A}}$ measured in the "down stream » cell is a measure of the flux of hydrogen, reoxidized in this cell, which have crossed the membrane. The palladium coating ensures the current transport. The permeation curve $i_{\mathrm{A}}=f(t)$ gives the variation of the hydrogen flux as 

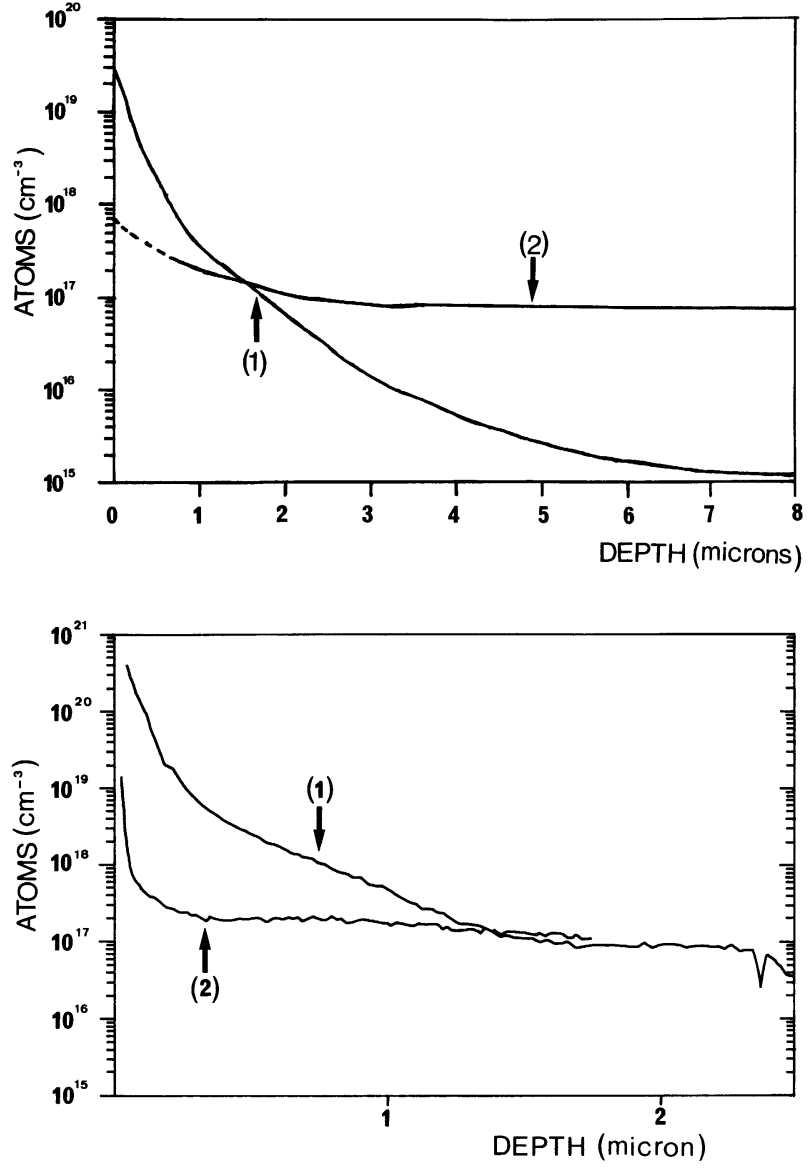

Fig. 9. - Deuterium S.I.M.S. profiles in silicon after deuterium microwave plasma annealing; a) $\mathrm{n}$ type $\left(10^{18}\right.$ at. P. $\left.\mathrm{cm}^{-3}\right)$; (1) $T=150^{\circ} \mathrm{C} ; t=3 \mathrm{~h}$; (2) $T=$ $320^{\circ} \mathrm{C} ; t=3 \mathrm{~h}$; b) undoped silicon; (1) $T=150{ }^{\circ} \mathrm{C}$; $t=3 \mathrm{~h}$; (2) $T=320^{\circ} \mathrm{C} ; t=3 \mathrm{~h}$.

a function of the time (Fig. 10). The mathematical deconvolution of this curve [21] leads to the apparent diffusion coefficient of hydrogen at room temperature. The thermodynamical conditions are such that the thermodynamic fugacity of hydrogen at the "entry face» is very high (larger than $10000 \mathrm{~atm}$.) [21]. As often in this kind of experiments, the mathematical analysis of the permeation curve shows that the Fick's law for diffusion is not satisfied. Such effect is usually a consequence of complex diffusion phenomena, more or less hindered by trapping of hydrogen by the surface or defects in the material [21]. In the present case, it was possible to show that the permeation curve of figure 10 can be described by two sets of apparent diffusion coefficients. One set of values («strongly-trapped» hydrogen) are of the order of $10^{-10} \mathrm{~cm}^{2} \cdot \mathrm{s}^{-1}$, the other set (« diffusible » hydrogen) is of the order of $10^{-9} \mathrm{~cm}^{2} \cdot \mathrm{s}^{-1}$ [22]. Both values are orders of magnitude larger than expected from the extrapolation to room temperature of the coefficients obtained at high temperature [19]. This result means again that

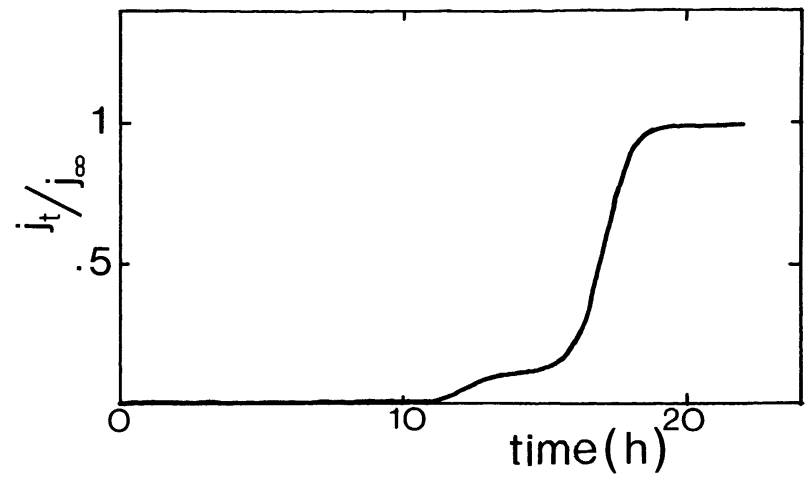

Fig. 10. - Hydrogen permeation flux normalised to steady state permeation flux, through $100 \mu \mathrm{m}$ thick membrane of p-type silicon as a function of time. Electrochemical introduction and detection of hydrogen at room temperature.

hydrogen diffusion is a very complex phenomenon. Under cathodic charging, i.e., under very high fugacities of atomic hydrogen, small amounts of this element can diffuse at rates much higher than the species detected by S.I.M.S. analysis of the plasma treated specimens.

\section{Hydrogen dopant interaction.}

Hydrogen introduced in p-type silicon has another important effect : for large quantities of hydrogen, one observes a neutralization of the dopant, leading to a spectacular increase of the near-surface resistivity and a strong decrease of the majority carrier concentration [16-18]. This effect has been observed and measured in p-type silicon submitted to the hydrogen plasma. Profiling of the majority carrier concentration under the surface is obtained by measurement of the voltage dependence of the capacity of a diode between mercury and the specimens. To extend the profile at large concentration, successive etchings of the surface are done.

The results (Fig. 11) confirm the strong neutralization effect of hydrogen on the dopant, in the regions where large quantities of hydrogen have diffused.

The neutralization depth is in good agreement with the concentration profiles of deuterium measured by S.I.M.S.

The physical mechanism of the dopant neutralization is still under discussion [23] but it is clear that, from the physicochemical point of view, such strong interaction will provoke important modifications of the diffusion mechanisms. We are here typically in the case of strong trapping phenomena.

\section{General discussion and conclusion.}

The problem of impurity-impurity and impuritydefects interactions in silicon and their consequences on electronic and photoelectrical properties of poly- 


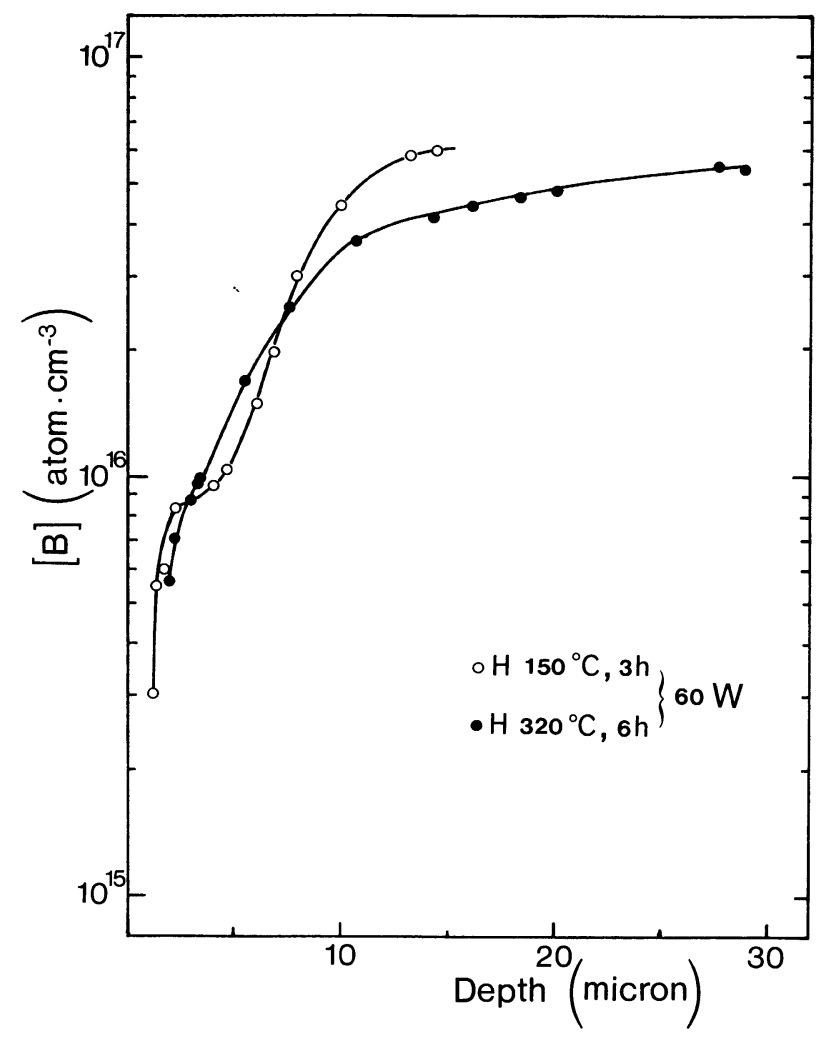

Fig. 11. - Acceptor profiles from the surface in p-type silicon $\left(6 \times 10^{16}\right.$ at. B. $\left.\mathrm{cm}^{-3}\right)$ after hydrogenation plasma annealing $\left(320^{\circ} \mathrm{C}, 6 \mathrm{~h} ; 150^{\circ} \mathrm{C}, 3 \mathrm{~h}\right)$.

crystalline silicon is far to be completely solved. The results given here indicate some interesting trends :

a) No noticeable grain-boundary diffusion of the dopant exists in the strongly textured large grain materials developed for photovoltaic applications.

b) The problem of impurity segregation, also dependent on the grain-boundary structure, is of major importance to understand the recombination behaviour of the boundaries and, probably, other defects (dislocations) [23].

c) The hydrogen passivation of the recombination centres cannot be only described in terms of structural defect interaction with hydrogen, as often done (e.g. dangling bond saturation by hydrogen); the microchemical aspect has to be taken into account, as recombination centres of chemical origin are also passivated by hydrogen.

d) This problem of hydrogen passivation is becoming even more complex if one takes into account the hydrogen dopant interaction. The fact that hydrogen is able to neutralize with a very high efficiency the acceptors must have an influence on the passivation mechanisms.

e) Hydrogen diffusion into silicon is not a simple mechanism. At least two or three species of hydrogen exist in the material with respectively decreasing solubilities and increasing diffusivities. Outgasing (exodiffusion) experiments as a function of temperature, and high temperature permeation experiments are necessary to separate correctly the behaviour of these species. At the present state, the hydrogendopant interaction seems to be the predominant factor influencing the diffusion phenomena.

\section{Acknowledgments.}

This study was partly financed by COMES (Commissariat à l'Energie Solaire), AFME (Agence Française pour la Maîtrise de l'Energie) and PIRSEM (Projet interdisciplinaire de Recherche du CNRS sur l'Energie et les Matières Premières).

The authors are grateful to J. Chevallier (CNRS, Meudon) and N. Proust (Thomson, Orsay) for the access to hydrogen and deuterium plasma equipments.

\section{References}

[1] Coll. Int. Semiconducteurs polycristallins, Perpignan, J. Physique Colloq. 43 (1982) C1.

[2] Proceeding of the Int. School of Mat. Sci. and Tech. The Ettore Majorana Centre Erice, Italy, July 115 (1984) (Springer) 1985.

[3] M.R.S. Fall, Meeting, Boston 1985, M.R.S. (1986).

[4] Second M.R.S. Europe Conference poly-micro-crystalline and amorphous semiconductors (June 1984), Strasbourg (France) Edited by P. Pinard and S. Kalbitzer (Editions de Physique) 1984.

[5] Baumgart, H., Leamy, H. J., Celler, G. K., Trimble, L. E., J. Physique Colloq. 43 (1982) C1-363.

[6] Belouet, C., Hervo, C., Mautref, M., Pages, C., Hervo, J., 16th IEEE, Photonet. Spec. Conf. (1982) San Diego (USA) p. 80.
[7] Chari, A., Thèse de $3^{\mathrm{e}}$ Cycle, Orsay (1980).

[8] Liotard, J. L., Biberian, R. and Cabane, J., $J$. Physique Colloq. 43 (1982) 213.

[9] Aucouturier, M., Chari, A., PIRDES, 14th IEEE Spec. Conference January (1980) St. Louis (USA) p. 1192.

[10] Sharko, R., Gervais, A. and Texier-Hervo, C., J. Physique Colloq. 43 (1982) 129.

[11] Rallon, O., Aucouturier, M., Hervo, C., Mautref, M., Belouet, C., Solar Cells 9 (1983) 149.

[12] Aucouturier, M., Rallon, O., Mautref, M. and Belouet, C., J. Physique Colloq. 43 (1982) C1117. 
[13] Battistella, F., Thèse Docteur-Ingénieur Toulouse (1985).

[14] Mautref, M., Lacroix, C., Belouet, C., Fages, C., Biotteau, B., Arnoult, F., Revue Phys. Appl. 19 (1984) 333.

[15] Seager, C. H., Sharp, D. J., Panitz, J. K. L., Hanoka, J. I., J. Physique Colloq. 43 (1982) C1-103.

[16] Pankove, J. L., VAnce, R. O. and Berkeyheiser, J. E., Appl. Phys. Lett. 45 (1984) 1100.

[17] Pankove, J. L., Maggee, C. W. and Vance, R. O., Appl. Phys. Lett. 47 (1985) 748.

[18] Johnson, N. M., Phys. Rev. B 31 (8) (1985) 5525.
[19] Pearton, S. J., J. Electron. Mater. 14a (1985) 737.

[20] Chari, A., Mierry, P. de, Aucouturier, M. and Gorochov, O., 7th Europ. Conf. Surf. Sci., Aix en Provence (France) (1984).

[21] Brass, A. M., Thèse Docteur ès Sciences, Orsay (1983).

[22] Mierry, P. de and Aucouturier, M., to be published.

[23] Capizzi, M., Mittiga, A., 2nd Int. Conf. on shallow Impurity centers, Trieste, July (1986).

[24] ZehaF, M., Thèse de Doct. ès Sciences, Marseille (1986). 